1 Cascading effects of canopy mortality drive long-term changes in understory diversity

2 in temperate old-growth forests of Europe

3

4 Running title: Cascading effects of canopy mortality

6 Thomas A. Nagel ${ }^{1}$, Giovanni Iacopetti ${ }^{2}$, Jernej Javornik ${ }^{1}$, Andrej Rozman ${ }^{1}$, Pieter De

$7 \quad$ Frenne $^{3}$, Federico Selvi ${ }^{2}$, Kris Verheyen ${ }^{3}$

8

$9 \quad$ Nagel, T.A. (corresponding author; tom.nagel@bf.uni-lj.si) ${ }^{1}$

10 Iacopetti, G. (giovanni.jacopetti@gmail.com)²

11 Javornik, J. (jernej.javornik@bf.uni-lj.si)) ${ }^{1}$

12 Rozman, A. (andrej.rozman@bf.uni-lj.si) ${ }^{1}$

13 De Frenne, P. (Pieter.DeFrenne@UGent.be) ${ }^{3}$

14 Selvi, F. (federico.selvi@unifi.it)²

15 Verheyen, K. (Kris.Verheyen@UGent.be) ${ }^{3}$

${ }^{1}$ Department of forestry and renewable forest resources, Biotechnical Faculty, University of Ljubljana, Ljubljana, Slovenia

${ }^{2}$ Department of Agriculture, Food, Environment and Forest Sciences, University of 20 Florence, Firenze, Italy

$21{ }^{3}$ Forest \& Nature Lab, Department of Environment, Ghent University, Ghent, Belgium 22

Funding information:

T.A.N. and J.J. received funding from the Pahernik Foundation and the Slovene Science Foundation (Program financing). K.V. benefited from an ERC Consolidator Grant (PASTFORWARD; grant no. 614839). P.D.F. received funding from the European Research Council (ERC) under the European Union's Horizon 2020 research and innovation programme (ERC Starting Grant FORMICA 757833). F.S. and G.I. benefited from grants by the Italian Ministry of University and Research (M.I.U.R.). 
Abstract

Questions: We investigated the influence of protracted mortality of a canopy dominant tree (Abies alba) on long-term understory dynamics. We ask 1) how tree regeneration and understory species diversity and composition changed over 32 years; and 2) whether the observed changes were mainly driven by mortality of A. alba.

Location: Three old-growth forest reserves dominated by A. alba and Fagus sylvatica in the Dinaric Mountains of Slovenia.

Methods: Tree layer and understory regeneration and herbs were surveyed in 147 plots across the three forest reserves in 1983 and 2015. Soils were also sampled in 2015. The study period coincides with a protracted period of increased A. alba mortality in the canopy layer associated with anthropogenic emissions.

Results: Between 1983 and 2015, the decline in canopy layer A. alba caused a recruitment pulse of $F$. sylvatica regeneration to the subcanopy tree layer across the three reserves. These changes were accompanied by a significant decline in plot level herb species richness. A model-based analysis of beta-diversity revealed significant community convergence during the study period, mainly caused by loss of rare species. Ellenberg values indicate that these changes were mainly driven by loss of understory light, while an increase in soil $\mathrm{pH}$ may have also played a role.

Conclusions: This observational study suggests that the long-term decline of $A$ alba resulted in a cascade of processes - widespread $F$. sylvatica recruitment that impeded penetration of light to the forest floor, and possibly a change in soil conditions due to the decline of coniferous litter. These changes caused a significant loss of herb diversity and homogenization of the understory community across the three sites. This study sheds light on the potential cascading consequences triggered by episodes of increased tree mortality resulting from global change type drivers.

Keywords: beech, fir decline, forest dieback, forest herbs, foundation species, oldgrowth, tree mortality, resurveys, semi-permanent plots, understory vegetation 
Introduction

There is widespread concern that global-change stressors, particularly drought accompanied by warmer temperatures and associated increases in pests and pathogens, may lead to forest die-off, decline, or chronic increases in tree mortality (van Mantgem et al. 2009; Jactel et al. 2012; Allen et al. 2015; Anderegg et al. 2015). Such mortality processes will likely cause cascading effects in forest ecosystems (Wardle et al. 2011; Millar \& Stephenson 2015; Shiels et al. 2015), especially when mortality is targeted on tree species that play a foundational role in a given forest community. Loss of foundational tree species have been documented to cause important changes to various properties and processes of forest ecosystems, including forest microclimate, understory herbs and tree regeneration, invertebrate communities, soil and litter properties, decomposition rates, and nutrient cycling (Ellison et al. 2005; Sackett et al. 2011; Lustenhouwer et al. 2012; Orwig et al. 2013; Kendrick et al. 2015).

Abies alba (silver fir), a conifer species distributed across mountain regions of the European temperate and Mediterranean zones (Mauri et al. 2016), shares many of the characteristics of a foundation tree species (sensu Ellison et al. 2005). It is both locally abundant and widespread over large regions, and has ecological traits that make a unique contribution to its habitat. It primarily occurs in mixed forests with Fagus sylvatica (beech), where it often represents a large proportion of stand-level basal area. It is one of the tallest and most shade tolerant tree species in Europe, traits which together contribute to the structural heterogeneity and resource use complementarity of mixed species stands (Tinner et al. 2013; Nagel et al. 2014; Forrester 2014). Abies alba has a strong influence on understory microclimate and soil properties due to the deep shade and litter cast from the canopy (Augusto et al. 2002; Augusto et al. 2003; Pizzeghello et al. 2006; Paluch \& Gruba 2012). Finally, both living and dead trees of $A$. alba support a diverse assemblage of flora and fauna (Lagana et al. 2000; Brändle \& Brandl 2001; Floren \& Gogala 2002; Táborska et al. 2015). protracted decline characterized by increased levels of morbidity and mortality during the 1970s-1990s (Diaci et al. 2011), now thought to be largely the result of high levels of atmospheric $\mathrm{SO}_{2}$ pollution (Elling et al. 2009). For some populations that experienced more severe dieback, this event is analogous to the global-change type dieback that is gaining attention in the literature, and affords a unique glimpse into the 
long-term effects of such events on forest ecosystem dynamics. Few studies, however, have examined how this episode of increased mortality influenced long-term processes and patterns, such as tree regeneration and understory herb dynamics (e.g. Nagel et al. 2015). Changes to the canopy can exert an important influence on understory communities via changes in light, microclimate, and soils (Augusto et al. 2002; Wulf \& Naaf 2009; Verheyen et al. 2012; Woods et al. 2012; De Frenne et al. 2013).

Understanding these mechanistic links between the canopy and understory, particularly for the herbaceous community that represents most of the plant diversity in temperate forests (Gilliam 2007), will be important for developing effective conservation and forest management strategies under global change.

Because canopy mortality and subsequent changes to forest ecosystems may play out over years to decades, understanding the dynamics of such systems requires direct observations over long time scales. We take advantage of long-term (1983-2015) resurveys of forest structure and understory vegetation in three temperate old-growth forest reserves in the Dinaric Mountains of Slovenia. The three forests have similar site conditions and have all experienced a relatively severe decline of $A$. alba during the study period, allowing a unique opportunity to examine how long-term mortality of a canopy dominant influences tree regeneration and understory herbaceous diversity. Another novel aspect of this study is that understory resurvey data are particularly rare in old-growth forest conditions in the temperate zone of Europe. Many of the resurvey studies in Europe have attributed long-term changes in herbaceous communities to forest canopy change resulting from management activities, such as the development of more closed canopy forests due to declines in harvesting intensity or abandonment of traditional management practices (e.g. coppicing) (Brunet et al. 1997; Baeten et al. 2009; Hédl et al. 2010; Baeten et al. 2010; Verheyen et al. 2012; De Frenne et al. 2013). Given that forest management is likely to confound the interpretation of understory dynamics, working in old-growth conditions allowed us to focus on the effects of $A$. alba dieback on the understory. Specifically, we ask 1) how tree regeneration and understory species diversity and composition changed in the old-growth forests over $30+$ years; and 2) are the observed changes mainly driven by mortality of $A$. alba?

Material and Methods

Study area 
Sampling was carried out in three old-growth forest reserves, Rajhenavski Rog

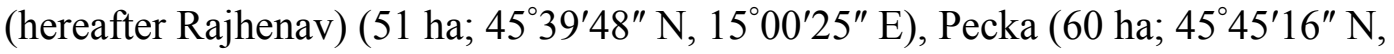

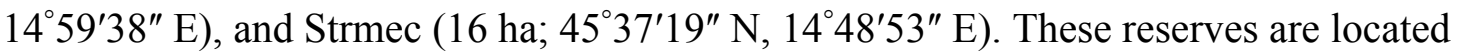
within a large forested region of southeastern Slovenia, situated in the northern Dinaric Mountain range. The temperate climate in the region receives approximately $1600 \mathrm{~mm}$ of annual precipitation, which is relatively evenly distributed throughout the year; the mean annual temperature at the nearest meteorological station (Kočevje; $461 \mathrm{~m}$ a.s.1.; approx. $4-16 \mathrm{~km}$ from the study sites) was $8.4{ }^{\circ} \mathrm{C}$ for the period $1961-1990$, and $8.8{ }^{\circ} \mathrm{C}$ from 1981-2010. These long-term averages at the station would correspond to an annual temperature closer to $6{ }^{\circ} \mathrm{C}$ at the elevation of the study locations, which all lie on the upper plateau of the mountain range between $800-940 \mathrm{~m}$ a.s.1. The sites occur on limestone bedrock and soils are predominantly Eutric Cambisols and Rendzic Leptosols (Grčman et al. 2015), which can vary considerably in depth due to the underlying karst geology, typified by sinkholes and occasional rock outcrops.

Forests in the three reserves are dominated by A. alba and F. sylvatica. A number of other less shade tolerant tree species are sporadically present, including Acer pseudoplatanus, Ulmus glabra, Fraxinus excelsior, and Picea abies. These sites have stand structural features typical of temperate old-growth forests, including complex structure, canopy trees that often exceed $80 \mathrm{~cm}$ in diameter and $40 \mathrm{~m}$ in height, and large amounts of standing and lying deadwood (Nagel et al. 2017). While there is no historical evidence that these stands have ever been managed, they have all been indirectly influenced by anthropogenic drivers, including air pollution that presumably played an important role in the dieback of $A$. alba, climate change, and high population densities of red deer. The latter has resulted in chronic browsing of palatable tree species, particularly A. alba, causing a pronounced recruitment failure across the region

162 (Nagel et al. 2015). Both of these processes have been well documented during the time period of the study. Population densities of red deer, reconstructed from archival hunting data, indicate that densities are high but have remained relatively stable over the past three decades (i.e. approximately 12-15 deer $/ \mathrm{km}^{2}$ ) (Nagel et al. 2015). To document the dieback of $A$. alba, we draw upon archival data of the Slovenian Forest Service, which surveys each reserve approximately every decade, whereby all live trees within entire reserves are tallied in $5 \mathrm{~cm}$ diameter classes. A comparison of recent and past inventories (the closest inventory years to those of the vegetation surveys) shows a clear decline in the density of $A$. alba trees across nearly all diameter classes, and a 
marked decline of canopy sized trees (i.e. trees $>30 \mathrm{~cm} \mathrm{DBH}$ ) across the three reserves based on multiple inventories during the past 40 years (Figure 1).

Field measurements

Vegetation surveys were carried out in each of the study sites in 1983 as part of a larger national level inventory of old-growth forests reserves in Slovenia (Hočevar et al. 1995). Across the entire area of each reserve, $7 \times 7 \mathrm{~m}$ plots were placed on a systematic 1-ha grid, for a total of 62 plots in Rajhenav, 64 plots in Pecka, and 21 plots in Strmec. Within each plot, all vascular plants were recorded in herb, shrub, and tree layers. The herb layer consisted of all herbaceous and woody species, while the shrub layer only included woody species. The tree layer in 1983 was split into bottom, middle, and upper stratum height classes and was recorded within a larger circular plot with a radius of $20 \mathrm{~m}$ extending from the center of each vegetation plot (see Appendix S1 for details). The abundance of each species was estimated using the following scale: $1-5$ specimens; $6-10$ specimens; $>11$ specimens and $<10 \%$ cover; $11-20 \%$ cover; 21 $40 \% ; 41-60 \% ; 61-80 \%$; and $81-100 \%$.

In 2015, we resurveyed all plots in each reserve from May to July, when both spring ephemerals were still visible and late summer species were sufficiently developed. Species abundance was estimated using the same scale as in the original survey. Plots were not permanently located in the original survey, but were drawn on detailed maps. These maps were georeferenced to obtain coordinates of plot centers, which were used in combination with field notes taken during the original inventories (information on topography, sink holes, rock outcrops, etc.) to relocate plots in the field. Plot locations were also double checked to ensure that the distance and bearing between plots matched the original grid. Plot size and vegetation sampling matched the original approach and cover estimation followed the same scale described above. We nevertheless keep in mind that relocation and observer errors can be significant (Verheyen et al. 2018), such that interpretation should be done with care.

Soils were also sampled in 2015 to characterize plot level site conditions. Sampling was carried out on a subset of 5 locations within each plot (i.e. corners and center). The depth of the ectorganic horizon was recorded and then removed; a $10 \mathrm{~cm}$ deep sample of mineral soil was then sampled using a $3 \mathrm{~cm}$ diameter auger. These subsamples were combined, dried to constant weight at $40^{\circ} \mathrm{C}$ for $48 \mathrm{~h}$, ground, and 
sieved over a $2 \mathrm{~mm}$ mesh. Samples were analysed for $\mathrm{pH}-\mathrm{KCl}$ by shaking a 1:5 ratio soil/ $\mathrm{KCl}(1 \mathrm{M})$ mixture for $5 \mathrm{~min}$. at $300 \mathrm{rpm}$ and measured with a $\mathrm{pH}$ meter (Orion 920A with pH electrode, model Ross Sure-flow 8172 BNWP, Thermo Scientific Orion, USA). For total $\mathrm{N}$ and $\mathrm{C}$, the samples were combusted at $1200^{\circ} \mathrm{C}$ and gases were measured with a thermal conductivity detector in a CNS elemental analyzer (vario Macro Cube, Elementar, Germany).

To augment our data on understory changes during the study period, we also compiled published and original archival data on regeneration densities of $F$. sylvatica (by height class) surveyed at different times during the period covered by the study. These regeneration inventories were carried out with a relatively large number of plots systematically distributed across reserves, and provide a good indication of reserve wide changes in regeneration structure over time. For a detailed description of these inventories, refer to Appendix S2.

\section{Data analyses}

We first examined variation in soil characteristics among the three reserves because this could confound our interpretation of understory dynamics. Although plot level soil $\mathrm{pH}$ and $\mathrm{C} / \mathrm{N}$ ratio varied widely within individual reserves, there was broad overlap among the three reserves (Appendix S3). Soils were therefore sufficiently similar to allow for further examination of how changes to the canopy across the reserves influenced understory dynamics.

The second step in the analysis focused on characterizing the changes in the tree canopy and regeneration layers over the 32-year study period. To prepare the data for this step, cover estimates for each species were transformed from the scale used in the field surveys to cover values (Appendix S1). We also combined several of the vegetation layers within each survey year to make the data more comparable between surveys; the final layer structure used in the analyses consisted of the herb (all herb species; woody species less than $30 \mathrm{~cm}$ in height), regeneration (30 cm - $5 \mathrm{~m}$ in height), subcanopy (5 - 20 m), and canopy layers (>20 m) (Appendix S1). Changes in the cover of each layer were examined with paired t-tests, taking into account the dependence of the old and new surveys.

The third part of the analysis focused on changes in the understory herb layer across the sample period, and included several measures of $\alpha, \beta$, and $\gamma$ diversity. Alpha 
$(\alpha)$ diversity was calculated as species richness and Shannon's Index for every plot using the vegan package in $\mathrm{R}$ (Oksanen et al. 2017). Beta ( $\beta$ ) diversity was estimated as model-based beta diversity using the approach of Baeten et al. (2014), which quantifies changes in community heterogeneity over time using presence/absence data, providing a general indication of community convergence or divergence. Gamma $(\gamma)$ diversity was based on reserve-scale species richness and total species richness across all three reserves. We also performed an indicator species analysis to assess the strength and statistical significance of the change in herb species occurrence between the two surveys. This analysis was done with the "indicspecies" R package (Cáceres \& Legendre 2009).

The fourth part of the analyses examined potential mechanisms of observed changes based on proxies for environmental conditions. We calculated plot level Ellenberg indicator values for light, temperature, soil moisture, soil reaction $/ \mathrm{pH}$, and soil nitrogen for each survey year; these indicator values allow inference into the underlying drivers of understory dynamics during the survey period (Diekmann 2003). Indicator values were calculated according to Pignatti (2005), who revised Ellenberg's values for the flora of Italy (the northeastern region of Italy has a similar flora to Slovenia). Note that the calculations presented here were weighted with species cover; calculations based only on the presence/absence data gave comparable results. Wilcoxon signed rank tests for paired samples were used to compare measures of diversity and indicator values between the two survey years for individual reserves. Additionally, we performed a linear mixed effects analysis to examine changes across the three reserves for the same measures of diversity and indicator values, with reserve as a random effect and survey year as a fixed effect; this analysis was carried out with lme4 (Bates et al. 2015). All analyses were performed in R (R Core Team 2018).

Results

Tree cover and regeneration dynamics

Across the three reserves, there were consistent changes in the tree layers between 1983 and 2015. Canopy layer cover declined in all three reserves, although the change was only significant in Pecka and Rajhenav (Fig 2a). These changes in canopy 
272 cover are consistent with the decline of $A$. alba across the reserves during the past four

273 decades (Fig 1). The decline in tree canopy cover was accompanied by a consistent

274 increase in cover of the subcanopy and regeneration layers during the study period

275 across the reserves (Fig 2b,c). Both of these layers were dominated by $F$. sylvatica in all

276 three reserves. These changes were significant for Pecka and Rajhenav, and were

277 particularly pronounced in the subcanopy layer for each reserve.

278 Changes in cover of the different canopy layers are consistent with available

279 archival data on regeneration densities (Table 1). In both Rajhenav and Pecka, from

280 which we have sufficient archival data of repeated inventories, seedlings (10 - 50 cm in

281 height) of $F$. sylvatica decreased from approx. $15000 \mathrm{ha}^{-1}$ in the early 1980 s to approx.

$2825000 \mathrm{ha}^{-1}$ in the $2000 \mathrm{~s}$. In contrast, the density of large saplings and pole sized trees

283 (200 cm in height to $10 \mathrm{~cm}$ diameter at breast height) increased from several hundred

284 per hectare in the 1980 s to over $3000 \mathrm{ha}^{-1}$ in the 2000 s. Although these inventories are

285 only snapshots in time, they indicate a clear recruitment pulse of $F$. sylvatica from small

286 seedlings to taller layers of the understory and subcanopy during the past four decades.

287 Only one inventory was available for Strmec in the year 2000, when there was a high

288 density of F. sylvatica saplings; many of these individuals recruited to the pole stage

289 during the course of the study period, but we lack recent data on densities.

Herb-layer response

There were marked decreases in Gamma-diversity for each reserve and the whole study region; across all three reserves, there was a decrease from 159 different species in the 1983 inventory to 127 species in 2015 (Table 2). There was also a significant decline in plot level species richness and Shannon diversity from 1983 to 2015 within each reserve (Fig 3, Table 2). Changes in species evenness were not consistent across the three reserves (Table 2).

The model-based analysis of beta-diversity highlighted significant community convergence between 1983 and 2015 for each reserve and for the pooled dataset $(\Delta D=-$ 3554; $P<0.001$ ) (Appendix S4), indicating a pronounced process of floristic homogenization in the study region. This process was almost exclusively driven by initially rare species (i.e. those present in $<10 \%$ of plots in 1983 inventories) that

304 became rarer or entirely absent over time, such that they contributed less to

305 heterogeneity among plots (Fig 4). Only a few species were significantly community- 
306 divergent in the pooled dataset; these primarily included species that were initially very common that decreased over time, such as Oxalis acetosella, Daphne mezereum, and

308 Festuca altissima. The indicator species analysis revealed a large number of species that were significantly associated with the old survey, while there were no species that were associated with the recent survey (Appendix S5). Many of the species that were associated with the old survey and showed strong declines included a number of "gap" species that require higher understory light levels, such as Rubus species, Salvia glutinosa, Fragaria vesca, Bromopsis ramosa, and Lonicera species. Across all the sites, only a few herb species consistently increased in frequency and cover, such as the spring ephemerals Anemone nemorosa, Arum maculatum, and Cardamine enneaphyllos. different indicators and reserves (Table 2, Fig 5). The mean index for light significantly decreased for all three reserves and the pooled dataset (Appendix S6). The only other indicator that showed a significant change on the pooled dataset was soil reaction $/ \mathrm{pH}$, which increased between the surveys (Appendix S6). Changes in other indicators, including soil moisture, temperature, and nitrogen, were either non-significant or were inconsistent among sites.

Discussion

We observed significant biodiversity losses and homogenization of the herbaceous understory plant community over three decades in the three old-growth forests sites. The dynamics of both the tree and herbaceous community indicate a cascading influence of $A$. alba mortality. The long-term decline of $A$. alba in the canopy layer resulted in a protracted recruitment pulse of $F$. sylvatica. This subcanopy layer of large $F$. sylvatica saplings and pole-sized trees that developed over the past few decades currently covers relatively large areas of the reserves. When $F$. sylvatica is leafed out, the amount of light that reaches the forest floor beneath this subcanopy layer is very low. Although our observational data cannot provide a rigorous mechanistic explanation, we suspect that the decline in understory light was the main mechanism that caused the loss in herb diversity and homogenization of the understory community over time across the sites.

The only Ellenberg values that showed significant changes in the pooled dataset included a decrease in light and an increase in soil reaction $/ \mathrm{pH}$, both of which are 
340 consistent with the cascading effects triggered by the loss of $A$. alba in the canopy.

341 Minimum levels of diffuse light beneath dense patches of $F$. sylvatica saplings and

342 pole-sized trees measured at the study sites were as low as 1.10\% (Adamič 2016). This

343 likely explains the decline of light demanding species that typically occur in forest gaps,

344 such as Salvia glutinosa, Fragaria vesca, and Rhamnus fallax (Fig 6). Moreover, these

345 low light levels (e.g. $<2 \%$ ) likely fall short of the requirements of even the most shade

346 tolerant herb species (Leuschner \& Ellenberg 2017). For example, O. acetosella and

347 Galium odoratum, two of the most shade tolerant and abundant species in the study

348 showed a marked loss of cover during the study period (Fig 6). Likewise, species that

349 maintain green foliage throughout the summer, such as Brachypodium sylvaticum, $G$.

350 odoratum, Hordelymus europaeus, and Omphalodes verna, may be particularly prone to 351 the deep shade cast by F. sylvatica (Fig 6) (Schmidt 2009). The marked decline in light

352 was likely the main driver for the pronounced decline or complete loss of many of the

353 rare species, especially those with moderately higher light requirements, which contributed to the strong pattern of community convergence for most species. Some of the few species that increased in frequency and cover during the study interval were spring ephemerals, including A. nemorosa, A. maculatum, and C. enneaphyllos (Fig 6). These species have likely benefited from increased light early in the growing season (prior to leaf-out of $F$. sylvatica, which has relatively late leaf out phenology) due to the loss of $A$. alba in the canopy. This is consistent with the loss of spring ephemerals that has been documented when conifers are planted on broadleaf forest sites (Pigott 1990). It is also possible that spring ephemerals may have additionally benefited due to the decline in cover of other dominant competitors in the herb layer, such as $O$. acetosella or G. odoratum (Fig 6) (Eber 1972).

In addition to the loss of light, a secondary mechanism contributing to the understory changes observed here could be associated with changes in litter characteristics. Fagus sylvatica produces leaf litter that differs in physical and chemical properties compared to the coniferous litter and humus of $A$. alba. The decrease in soil acidity indicated by the change in the herb community is also consistent with the decline of A. alba and replacement by F. sylvatica. Working in mixed Fagus-Abies stands, Paluch and Gruba (2012) found increased organic matter accumulation, lower $\mathrm{pH}$, and lower soil moisture when the local density of $A$. alba increased. Augusto et al

372 (2003) reported thicker litter with higher $\mathrm{C} / \mathrm{N}$ ratios and lower $\mathrm{pH}$ for soils under $A$.

373 alba compared to those under $F$. sylvatica, although these differences were moderate; 
likewise, they reported that herb species beneath $A$. alba were typical of moderately more acidic and nutrient poor conditions compared to herbs growing under $F$. sylvatica. Woziwoda and Kopec (2015) reported similar changes in the herb layer in stands that experienced a long-term loss of $A$. alba and replacement by broadleaf species; they documented an increase in nitrophilous species and a decline in species that tolerate more nutrient poor and acidic conditions, presumably due to the decline in conifer litter and the increase in easily decomposable broad leaf litter. According to phytosociological literature, herb species that are typically associated with moderately acidic conditions or a larger component of $A$. alba include species such as Dryopteris filix-mas, Oxalis acetosella, and F. altissima (Pignatti \& Pignatti 2013; Leuschner \& Ellenberg 2017), all of which significantly declined across the study sites. However, because we do not have data on soil chemistry from the initial inventory, this interpretation should be treated with caution.

Indeed, a number of other drivers, including deer browsing, climate change, and nitrogen deposition, may have played some role in the understory dynamics observed in our dataset. The density of red deer is high in the study area and has remained high throughout the past three decades, at about 15 deer $\mathrm{km}^{-2}$ (Nagel et al. 2015). Most species, regardless of palatability, declined during the study period, while A. nemorosa, documented as a preferred browse species (Pellerin et al. 2010), increased in cover. These patterns suggest that deer browsing was unlikely a primary driver of the understory herb dynamics observed here. However, herbivory has likely had an indirect effect on herb communities via its influence on tree regeneration. Preferential browsing has resulted in a long-term recruitment failure of $A$. alba, thereby facilitating the contemporary dominance of F. sylvatica in the understory (Nagel et al. 2015). Longterm nitrogen deposition and ongoing climate change may have also contributed to the diversity declines (Stevens et al. 2004; Scheffers et al. 2016), but there was no clear pattern for these drivers based on the Ellenberg indicator values. Several other studies have documented that loss of light from canopy shading overrides the influence of nitrogen deposition and climate warming on understory communities (Verheyen et al. 2012; De Frenne et al. 2013; De Frenne et al. 2015; Verheyen et al. 2017; Helm et al. 2017). We suspect that this has likely been the case in this study as well.

In addition to the cascading influence of $A$. alba decline, our results highlight the importance of non-equilibrial dynamics in these old-growth forest systems. The traditional view of forest dynamics, particularly in Central Europe, maintains that the 
408 forest structure and composition of old-growth systems are stable at stands scales,

409 regulated by a shifting mosaic of small patches created by relatively continuous

410 mortality of old canopy trees. A more contemporary view suggests that old-growth

411 systems are in a continuous state of change in response to historical disturbances

412 (Woods 2000; Woods 2004; Nagel et al. 2014). Given the important influence that tree

413 canopies may exert on understory herbs via changes in light and litter characteristics, it

414 follows that herb communities would also exhibit long-term non-equilibrial dynamics in

415 old-growth forest systems. The results of our study are consistent with another multi-

416 decade study of understory dynamics in temperate old-growth forests of Michigan that

417 documented declines in fine-scale diversity; the authors attributed these changes to

418 long-term competitive filtering following historical disturbances that cause moderate

419 severity damage to forest canopies (Woods 2004; Woods et al. 2012).

420

Conclusions

Unlike the typical natural disturbances that cause abrupt changes to forests in the temperate region of Europe, such as strong winds, heavy snow, or icestorms (Nagel et al. 2017), the decline of $A$. alba was a species-specific and protracted episode of increased mortality, a pattern that may be characteristic of the global-change type dieback of forests due to a combination of nonnative insects, pathogens, and drought under an increasingly warmer climate (Allen et al. 2010; Anderegg et al. 2015). In cases when forest die-back targets foundational tree species (sensu Ellison et al. 2005), the consequences for various ecosystem properties and functions may be particularly pronounced. The effects of widespread hemlock mortality from the woolly adelgid in the eastern USA is a thoroughly studied example (Ellison et al. 2005; Ellison 2014). In many mixed Fagus-Abies type forests in Europe, the past decline of A. alba and ongoing recruitment failure due to overbrowsing may result in an analogous situation.

435 We suspect that the continued loss of $A$. alba will likely result in a number of long-term changes to these forest ecosystems, including the homogenization of the understory environment and decreased herb diversity. These changes could have consequences for ecosystem function (Clavel et al. 2011), but would require additional trait based analyses (Baeten et al. 2014). The understory changes documented here may shed light on some of the potential cascading consequences triggered by protracted episodes of widespread tree mortality resulting from global change type drivers. Ongoing examples 
include the invasive fungal pathogen (Hymenoscyphus fraxineus) affecting ash trees across Europe (Pautasso et al. 2013), and numerous nonnative insects and pathogens in North America, such as white pine blister rust, sudden oak death, beech bark disease, and the emerald ash borer (Lovett et al. 2016).

Acknowledgements: We thank the undergraduate students from the University of Ljubljana, Luka Šparl, Polona Sušnik, and Tadej Murn, for help with field work, and Igor Dakskobler for help with species identification. The manuscript was improved by helpful comments of two anonymous reviewers.

Author contributions:

T.A.N., K.V., P.D.F, and F.S. conceived of the research idea; J.J., G.I., and A.R. collected data; G.I., J.J., and A.R., with help from P.D.F. and K.V performed statistical analyses; T.A.N., with contributions from all authors, wrote the paper; all authors discussed the results and commented on the manuscript.

Data Availability Statement: Data are available through forestREplot (www.forestreplot.ugent.be)

\section{References}

Adamič, M. 2016. Light climate and structural characteristics of Dinaric mixed mountain managed and old-growth forest. Doctoral Dissertation, University of Ljubljana, Biotechnical Faculty, Ljubljana.

Allen, C.D., Macalady, A.K., Chenchouni, H., Bachelet, D., McDowell, N., Vennetier, M., Kitzberger, T., Rigling, A., Breshears, D.D., Hogg, E.H., Gonzalez, P., Fensham, R., Zhang, Z., Castro, J., Demidova, N., Lim, J.H., Allard, G., Running, S.W., Semerci, A., \& Cobb, N. 2010. A global overview of drought and heat-induced tree mortality reveals emerging climate change risks for forests. Forest Ecology and Management 259: 660-684.

Allen, C.D., Breshears, D.D., \& McDowell, N.G. 2015. On underestimation of global vulnerability to tree mortality and forest die-off from hotter drought in the Anthropocene. Ecosphere 6: 1-55. 
475 Anderegg, W.R.L., Hicke, J.A., Fisher, R.A., Allen, C.D., Aukema, J., Bentz, B., Hood, 476 S., Lichstein, J.W., Macalady, A.K., McDowell, N., Pan, Y., Raffa, K., Sala, A., Shaw, 477 J.D., Stephenson, N.L., Tague, C., \& Zeppel, M. 2015. Tree mortality from drought, 478 insects, and their interactions in a changing climate. New Phytologist 208: 674-683. 479 Augusto, L., Dupouey, J.-L., \& Ranger, J. 2003. Effects of tree species on understory 480 vegetation and environmental conditions in temperate forests. Annals of Forest Science $481 \quad 60: 823-831$.

482 Augusto, L., Ranger, J., Binkley, D., \& Rothe, A. 2002. Impact of several common tree 483 species of European temperate forests on soil fertility. Annals of Forest Science 59: $484233-253$.

485 Baeten, L., Bauwens, B., De Schrijver, A., De Keersmaeker, L., Van Calster, H., 486 Vandekerkhove, K., Roelandt, B., Beeckman, H., \& Verheyen, K. 2009. Herb layer 487 changes (1954-2000) related to the conversion of coppice-with-standards forest and soil 488 acidification. Applied Vegetation Science 12: 187-197.

489 Baeten, L., Hermy, M., Van Daele, S., \& Verheyen, K. 2010. Unexpected understorey 490 community development after 30 years in ancient and post-agricultural forests: Land 491 use and 30-year forest development. Journal of Ecology 98: 1447-1453.

492 Baeten, L., Warton, D.I., Van Calster, H., De Frenne, P., Verstraeten, G., Bonte, D., 493 Bernhardt-Römermann, M., Cornelis, J., Decocq, G., Eriksson, O., Hédl, R., Heinken, 494 T., Hermy, M., Hommel, P., Kirby, K., Naaf, T., Petř́k, P., Walther, G.-R., Wulf, M., \& 495 Verheyen, K. 2014. A model-based approach to studying changes in compositional 496 heterogeneity (M. Spencer, Ed.). Methods in Ecology and Evolution 5: 156-164.

497 Bates, D., Maechler, M., Bolker, B., \& Walker, S. 2015. Fitting Linear 498 Mixed-Effects Models Using lme4. Journal of Statistical Software 67: 1-48.

499 Brändle, M., \& Brandl, R. 2001. Species richness of insects and mites on trees:

500 expanding Southwood. Journal of Animal Ecology 70: 491-504.

501 Brunet, J., Falkengren-Grerup, U., Rühling, \AAke, \& Tyler, G. 1997. Regional 502 differences in floristic change in South Swedish oak forests as related to soil chemistry 503 and land use. Journal of Vegetation Science 8: 329-336.

504 Cáceres, M.D., \& Legendre, P. 2009. Associations between species and groups of sites: 505 indices and statistical inference. Ecology 90: 3566-3574.

506 Clavel, J., Julliard, R., \& Devictor, V. 2011. Worldwide decline of specialist species: 507 toward a global functional homogenization? Frontiers in ecology and the environment 508 9: $222-228$. 
De Frenne, P., Rodriguez-Sanchez, F., Coomes, D.A., Baeten, L., Verstraeten, G.,

510 Vellend, M., Bernhardt-Romermann, M., Brown, C.D., Brunet, J., Cornelis, J., Decocq,

511 G.M., Dierschke, H., Eriksson, O., Gilliam, F.S., Hedl, R., Heinken, T., Hermy, M.,

512 Hommel, P., Jenkins, M.A., Kelly, D.L., Kirby, K.J., Mitchell, F.J.G., Naaf, T.,

513 Newman, M., Peterken, G., Petrik, P., Schultz, J., Sonnier, G., Van Calster, H., Waller,

514 D.M., Walther, G.-R., White, P.S., Woods, K.D., Wulf, M., Graae, B.J., \& Verheyen,

515 K. 2013. Microclimate moderates plant responses to macroclimate warming.

516 Proceedings of the National Academy of Sciences 110: 18561-18565.

517 De Frenne, P., Rodríguez-Sánchez, F., De Schrijver, A., Coomes, D.A., Hermy, M.,

518 Vangansbeke, P., \& Verheyen, K. 2015. Light accelerates plant responses to warming.

$519 \quad$ Nature Plants 1: 15110.

520 Diaci, J., Rozenbergar, D., Anic, I., Mikac, S., Saniga, M., Kucbel, S., Visnjic, C., \&

521 Ballian, D. 2011. Structural dynamics and synchronous silver fir decline in mixed old-

522 growth mountain forests in Eastern and Southeastern Europe. Forestry 84: 479-491.

523 Diekmann, M. 2003. Species indicator values as an important tool in applied plant

524 ecology-a review. Basic and applied ecology 4: 493-506.

525 Elling, W., Dittmar, C., Pfaffelmoser, K., \& Rotzer, T. 2009. Dendroecological

526 assessment of the complex causes of decline and recovery of the growth of silver fir

527 (Abies alba Mill.) in Southern Germany. Forest Ecology and Management 257: 1175-

5281187.

529 Ellison, A.M. 2014. Experiments Are Revealing a Foundation Species: A Case Study of

530 Eastern Hemlock ( Tsuga canadensis ). Advances in Ecology 2014: 1-11.

531 Ellison, A., Bank, M., Clinton, B., Colburn, E., Elliott, K., Ford, C., Foster, D.,

532 Kloeppel, B., Knoepp, J., Lovett, G., Mohan, J., Orwig, D., Rodenhouse, N., Sobczak,

533 W., Stinson, K., Stone, J., Swan, C., Thompson, J., Von Holle, B., \& Webster, J. 2005.

534 Loss of foundation species: consequences for the structure and dynamics of forested

535 ecosystems. Frontiers in ecology and the environment 3: 479-486.

536 Floren, A., \& Gogala, A. 2002. Heteroptera from beech (Fagus sylvatica) and silver fir

537 (Abies alba) trees of the primary forest reserve Rajhenavski Rog, Slovenia. Acta

538 Entomologica Slovenica 10: 25-32.

539 Forrester, D.I. 2014. The spatial and temporal dynamics of species interactions in

540 mixed-species forests: From pattern to process. Forest Ecology and Management 312:

$541 \quad 282-292$. 
542 Gilliam, F.S. 2007. The Ecological Significance of the Herbaceous Layer in Temperate 543 Forest Ecosystems. BioScience 57: 845.

544 Grčman, H., Vidic, N.J., Zupan, M., Lobnik, F., Jones, A., \& Montanarella, L. (Eds.)

545 2015. Soils of Slovenia with soil map 1:250000. European Commission Joint Research

546 Centre (JRC).

547 Hédl, R., Kopecký, M., \& Komárek, J. 2010. Half a century of succession in a

548 temperate oakwood: from species-rich community to mesic forest. Diversity and

549 Distributions 16: 267-276.

550 Helm, N., Essl, F., Mirtl, M., \& Dirnböck, T. 2017. Multiple environmental changes

551 drive forest floor vegetation in a temperate mountain forest. Ecology and Evolution 7:

$552 \quad 2155-2168$.

553 Hočevar S., Batič F., Piskernik M., Martinčič A. 1995. Glive v pragozdovih Slovenije:

554 III. Dinarski gorski pragozdovi na Kočevskem in Trnovskem gozdu. (Strokovna in

555 znanstvena dela, 117). Ljubljana, Gozdarski inštitut Slovenije: 320 pp.

556 Jactel, H., Petit, J., Desprez-Loustau, M.-L., Delzon, S., Piou, D., Battisti, A., \&

557 Koricheva, J. 2012. Drought effects on damage by forest insects and pathogens: a meta-

558 analysis. Global Change Biology 18: 267-276.

559 Kendrick, J.A., Ribbons, R.R., Classen, A.T., \& Ellison, A.M. 2015. Changes in canopy

560 structure and ant assemblages affect soil ecosystem variables as a foundation species

561 declines. Ecosphere 6: 1-20.

562 Lagana, A., Salerni, E., Barluzzi, C., Perini, C., \& De Dominicis, V. 2000.

563 Mycocoenology in Abies alba Miller woods of Central-Southern Tuscany (Italy). Acta

564 societatis botanicorum poloniae 69: 293-298.

565 Leuschner, C., \& Ellenberg, H. 2017. Ecology of Central European Forests: Vegetation

566 Ecology of Central Europe. Springer International Publishing.

567 Lovett, G.M., Weiss, M., Liebhold, A.M., Holmes, T.P., Leung, B., Lambert, K.F.,

568 Orwig, D.A., Campbell, F.T., Rosenthal, J., McCullough, D.G., Wildova, R., Ayres,

569 M.P., Canham, C.D., Foster, D.R., LaDeau, S.L., \& Weldy, T. 2016. Nonnative forest

570 insects and pathogens in the United States: Impacts and policy options. Ecological

571 Applications 26: 1437-1455.

572 Lustenhouwer, M.N., Nicoll, L., \& Ellison, A.M. 2012. Microclimatic effects of the loss

573 of a foundation species from New England forests. Ecosphere 3: art26.

574 van Mantgem, P.J., Stephenson, N.L., Byrne, J.C., Daniels, L.D., Franklin, J.F., Fule,

575 P.Z., Harmon, M.E., Larson, A.J., Smith, J.M., Taylor, A.H., \& Veblen, T.T. 2009. 
Widespread Increase of Tree Mortality Rates in the Western United States. Science 323: $521-524$.

Mauri, A., de Rigo, D., \& Caudullo, G. 2016. Abies alba in Europe: distribution, habitat, usage and threats. In San-Miguel-Ayanz, J., de Rigo, D., Caudullo, G., Houston Durrant, T., \& Mauri, A. (eds.), European Atlas of Forest Tree Species, p. e01493b+.

581 Publ. Off. EU, Luxembourg.

582 Millar, C.I., \& Stephenson, N.L. 2015. Temperate forest health in an era of emerging 583 megadisturbance. Science 349: 823-826.

584 Nagel, T.A., Diaci, J., Jerina, K., Kobal, M., \& Rozenbergar, D. 2015. Simultaneous influence of canopy decline and deer herbivory on regeneration in a conifer-broadleaf forest. Canadian Journal of Forest Research 45: 266-275. Rozenbergar, D. 2017. Evaluating the influence of integrative forest management on old-growth habitat structures in a temperate forest region. Biological Conservation 216: 101-107.

Nagel, T.A., Mikac, S., Dolinar, M., Klopcic, M., Keren, S., Svoboda, M., Diaci, J., Boncina, A., \& Paulic, V. 2017. The natural disturbance regime in forests of the Dinaric Mountains: A synthesis of evidence. Forest Ecology and Management 388: 29-42. Nagel, T.A., Svoboda, M., \& Kobal, M. 2014. Disturbance, life history traits, and dynamics in an old-growth forest landscape of southeastern Europe. Ecological Applications 24: 663-679.

597 Oksanen, J., Blanchet, F.G., Friendly, M., Kindt, R., Legendre, P., McGlinn, D.,

598 Minchin, P.R., O'Hara, R. B., Simpson, G.L., Solymos, P., Stevens, M.H.H., Szoecs, E., 599 \& Wagner, H. (2017). vegan: Community Ecology Package. R package version 2.4-4.

600 https://CRAN.R-project.org/package=vegan

601 Orwig, D.A., Barker Plotkin, A.A., Davidson, E.A., Lux, H., Savage, K.E., \& Ellison, 602 A.M. 2013. Foundation species loss affects vegetation structure more than ecosystem 603 function in a northeastern USA forest. PeerJ 1: e41.

604 Paluch, J.G., \& Gruba, P. 2012. Effect of local species composition on topsoil 605 properties in mixed stands with silver fir (Abies alba Mill.). Forestry: An International 606 Journal of Forest Research 85: 413-426.

607 Pautasso, M., Aas, G., Queloz, V., \& Holdenrieder, O. 2013. European ash (Fraxinus 608 excelsior) dieback - A conservation biology challenge. Biological Conservation 158: $609 \quad 37-49$. 
610 Pellerin, M., Saïd, S., Richard, E., Hamann, J.-L., Dubois-Coli, C., \& Hum, P. 2010.

611 Impact of deer on temperate forest vegetation and woody debris as protection of forest

612 regeneration against browsing. Forest Ecology and Management 260: 429-437.

613 Pignatti, S., 2005. Valori di Bioindicazione delle piante vascolari della Flora d'Italia.

614 Braun-Blanquetia 39, 1-97.

615 Pignatti, E., \& Pignatti, S. 2013. Plant Life of the Dolomites: Vegetation Structure and

616 Ecology. Springer Berlin Heidelberg.

617 Pigott, C.D. 1990. The Influence of Evergreen Coniferous Nurse-Crops on the Field

618 Layer in Two Woodland Communities. The Journal of Applied Ecology 27: 448.

619 Pizzeghello, D., Zanella, A., Carletti, P., \& Nardi, S. 2006. Chemical and biological

620 characterization of dissolved organic matter from silver fir and beech forest soils.

621 Chemosphere 65: 190-200.

622 R Core Team (2018). R: A language and environment for statistical computing. R

623 Foundation for Statistical Computing, Vienna, Austria. URL https://www.R-

624 project.org/.

625 Sackett, T.E., Record, S., Bewick, S., Baiser, B., Sanders, N.J., \& Ellison, A.M. 2011.

626 Response of macroarthropod assemblages to the loss of hemlock (Tsuga canadensis), a

627 foundation species. Ecosphere 2: 1-16.

628 Schmidt, W. 2009. Vegetation. In Brumme, R. \& Khanna, P.K. (eds.), Functioning and 629 Management of European Beech Ecosystems, pp. 65-86. Ecological Studies. Springer

630 Berlin Heidelberg.

631 Scheffers, B.R., De Meester, L., Bridge, T.C.L., Hoffmann, A.A., Pandolfi, J.M.,

632 Corlett, R.T., Butchart, S.H.M., Pearce-Kelly, P., Kovacs, K.M., Dudgeon, D., Pacifici,

633 M., Rondinini, C., Foden, W.B., Martin, T.G., Mora, C., Bickford, D., \& Watson,

634 J.E.M. 2016. The broad footprint of climate change from genes to biomes to people.

635 SCIENCE 354

636 Shiels, A.B., Gonzalez, G., Lodge, D.J., Willig, M.R., \& Zimmerman, J.K. 2015.

637 Cascading Effects of Canopy Opening and Debris Deposition from a Large-Scale

638 Hurricane Experiment in a Tropical Rain Forest. BioScience 65: 871-881.

639 Stevens, C., Dise, N., Mountford, J., \& Gowing, D. 2004. Impact of nitrogen deposition

640 on the species richness of grasslands. SCIENCE 303: 1876-1879.

641 Táborska, M., Privetity, T., Vrska, T., \& Ódor, P. 2015. Bryophytes associated with two

642 tree species and different stages of decay in a natural fir-beech mixed forest in the

643 Czech Republic. Preslia 87: 387-401. 
644 Tinner, W., Colombaroli, D., Heiri, O., Henne, P.D., Steinacher, M., Untenecker, J., 645 Vescovi, E., Allen, J.R., Carraro, G., Conedera, M., \& others. 2013. The past ecology of 646 Abies alba provides new perspectives on future responses of silver fir forests to global 647 warming. Ecological Monographs 83: 419-439.

648 Verheyen, K., Baeten, L., De Frenne, P., Bernhardt-Römermann, M., Brunet, J., 649 Cornelis, J., Decocq, G., Dierschke, H., Eriksson, O., Hédl, R., Heinken, T., Hermy, M., 650 Hommel, P., Kirby, K., Naaf, T., Peterken, G., Petř́k, P., Pfadenhauer, J., Van Calster, 651 H., Walther, G.-R., Wulf, M., \& Verstraeten, G. 2012. Driving factors behind the eutrophication signal in understorey plant communities of deciduous temperate forests: Drivers of change in forest understorey vegetation. Journal of Ecology 100: 352-365. Verheyen, K., De Frenne, P., Baeten, L., Waller, D.M., Hédl, R., Perring, M.P., Blondeel, H., Brunet, J., Chudomelová, M., Decocq, G., \& others. 2017. Combining Biodiversity Resurveys across Regions to Advance Global Change Research. BioScience 67: 73-83.

658 Verheyen, K., Bažány, M., Chećko, E., Chudomelová, M., Closset-Kopp, D., Czortek, P., Decocq, G., De Frenne, P., De Keersmaeker, L., Enríquez García, C., Fabšičová, M.,

660 Grytnes, J.-A., Hederová, L., Hédl, R., Heinken, T., Schei, F.H., Horváth, S.,

661 Jaroszewicz, B., Jermakowicz, E., Klinerová, T., Kolk, J., Kopecký, M., Kuras, I., 662 Lenoir, J., Macek, M., Máliš, F., Martinessen, T.C., Naaf, T., Papp, L., Papp-Szakály, 663 Á., Pech, P., Petř́k, P., Prach, J., Reczyńska, K., Sætersdal, M., Spicher, F., Standovár, 664 T., Świerkosz, K., Szczęśniak, E., Tóth, Z., Ujházy, K., Ujházyová, M., Vangansbeke, 665 P., Vild, O., Wołkowycki, D., Wulf, M., \& Baeten, L. 2018. Observer and relocation errors matter in resurveys of historical vegetation plots. Journal of Vegetation Science.

667 (in press).

668 Wardle, D.A., Bardgett, R.D., Callaway, R.M., \& Van der Putten, W.H. 2011.

669 Terrestrial ecosystem responses to species gains and losses. Science 332: 1273-1277.

670 Woods, K.D. 2000. Dynamics in late-successional hemlock-hardwood forests over 671 three decades. Ecology 81: 110-126.

672 Woods, K.D. 2004. Intermediate disturbance in a late-successional hemlock- northern 673 hardwood forest. Journal of Ecology 92: 464-476.

674 Woods, K.D., Hicks, D.J., \& Schultz, J. 2012. Losses in understory diversity over three 675 decades in an old-growth cool-temperate forest in Michigan, USA. Canadian Journal of 676 Forest Research 42: 532-549. 
677 Woziwoda, B., \& Kopeć, D. 2015. Changes in the silver fir forest vegetation 50 years 678 after cessation of active management. Acta Societatis Botanicorum Poloniae 84: 177679187.

680 Wulf, M., \& Naaf, T. 2009. Herb layer response to broadleaf tree species with different 681 leaf litter quality and canopy structure in temperate forests. Journal of Vegetation 682 Science 20: 517-526.

683

684

685

686

687

688

689

690

691

692

693

694

695

696

697

698

699

700

701

702

703

704

705

706

707

708

709

710 
711 Table 1. Density of Fagus sylvatica regeneration $\left(\mathrm{N}-\mathrm{ha}^{-1}\right)$ by size class sampled at

712 different time periods during the course of the study. Only one inventory of Fagus

713 regeneration was available for the Strmec reserve.

\begin{tabular}{llccccc}
\cline { 3 - 6 } & & Rajhenav & & Pecka & Strmec \\
\hline Size class & Height / size range & 1984 & 2010 & 1980 & 2007 & 2000 \\
\hline seedlings & $10-50 \mathrm{~cm}$ & 15981 & 5012 & 14500 & 5640 & 15911 \\
saplings & $50-200 \mathrm{~cm}$ & 4508 & 6175 & 4786 & 4726 & 13778 \\
poles & $200 \mathrm{~cm}-10 \mathrm{~cm} \mathrm{dbh}$ & 161 & 3024 & 534 & 3569 & 376 \\
\hline
\end{tabular}

714

715

716

717

718 
719 Table 2.Changes in species diversity metrics and Ellenberg indicator values between 1983 and 2015 for the three old-growth forest reserves. SD =

720 standard deviation; $\mathrm{z}=\mathrm{z}$-value test statistic based on a Wilcoxon signed rank tests; n.s.: not significant; $* \mathrm{P}<0.05 ; * * P<0.01 ; * * * P<0.001$ ).

\begin{tabular}{|c|c|c|c|c|c|c|c|c|c|c|c|c|c|c|c|c|c|c|}
\hline & \multicolumn{6}{|c|}{ Pecka } & \multicolumn{6}{|c|}{ Rajhenav } & \multicolumn{6}{|c|}{ Strmec } \\
\hline & Mean 83 & SD 83 & Mean 15 & SD 15 & $\mathrm{z}$ & & Mean 83 & SD 83 & Mean 15 & SD 15 & $\mathrm{z}$ & & Mean 83 & SD 83 & Mean 15 & SD 15 & $\mathrm{z}$ & \\
\hline Species richness & 27.89 & 5.13 & 16.22 & 5.17 & -6.71 & $* * *$ & 25.71 & 4.50 & 18.19 & 4.92 & -6.16 & $* * *$ & 31.29 & 9.19 & 19.95 & 4.46 & -3.60 & $* * *$ \\
\hline Shannon diversity & 2.28 & 0.28 & 1.85 & 0.32 & -6.00 & $* * *$ & 2.14 & 0.26 & 2.02 & 0.32 & -2.33 & $*$ & 2.63 & 0.31 & 2.01 & 0.39 & -4.50 & *** \\
\hline Evenness & 0.69 & 0.07 & 0.67 & 0.08 & -1.35 & NS & 0.66 & 0.06 & 0.70 & 0.08 & -3.12 & $* *$ & 0.77 & 0.06 & 0.68 & 0.12 & -2.90 & $* *$ \\
\hline Gamma diversity & 107 & & 85 & & & & 99 & & 83 & & & & 127 & & 90 & & & \\
\hline \multicolumn{19}{|l|}{ Ellenberg Values } \\
\hline Light & 3.70 & 0.24 & 3.50 & 0.31 & -4.10 & $* * *$ & 3.87 & 0.27 & 3.47 & 0.30 & -5.75 & $* * *$ & 4.07 & 0.31 & 3.80 & 0.33 & -2.77 & ** \\
\hline Temperature & 4.99 & 0.16 & 4.93 & 0.17 & -2.59 & $* *$ & 4.79 & 0.10 & 4.82 & 0.17 & -1.29 & NS & 4.95 & 0.17 & 5.03 & 0.17 & -1.49 & NS \\
\hline Soil moisture & 5.28 & 0.12 & 5.15 & 0.18 & -5.35 & $* * *$ & 5.10 & 0.14 & 5.20 & 0.18 & -3.64 & $* * *$ & 5.10 & 0.14 & 5.09 & 0.16 & -0.58 & NS \\
\hline Soil pH & 6.76 & 0.32 & 6.84 & 0.36 & -1.73 & NS & 6.02 & 0.29 & 6.27 & 0.46 & -3.74 & $* * *$ & 6.82 & 0.22 & 6.84 & 0.33 & -0.47 & NS \\
\hline Nitrogen & 6.04 & 0.25 & 5.94 & 0.33 & -2.48 & $*$ & 5.64 & 0.23 & 5.74 & 0.33 & -1.90 & NS & 5.57 & 0.35 & 5.72 & 0.46 & -1.81 & NS \\
\hline
\end{tabular}



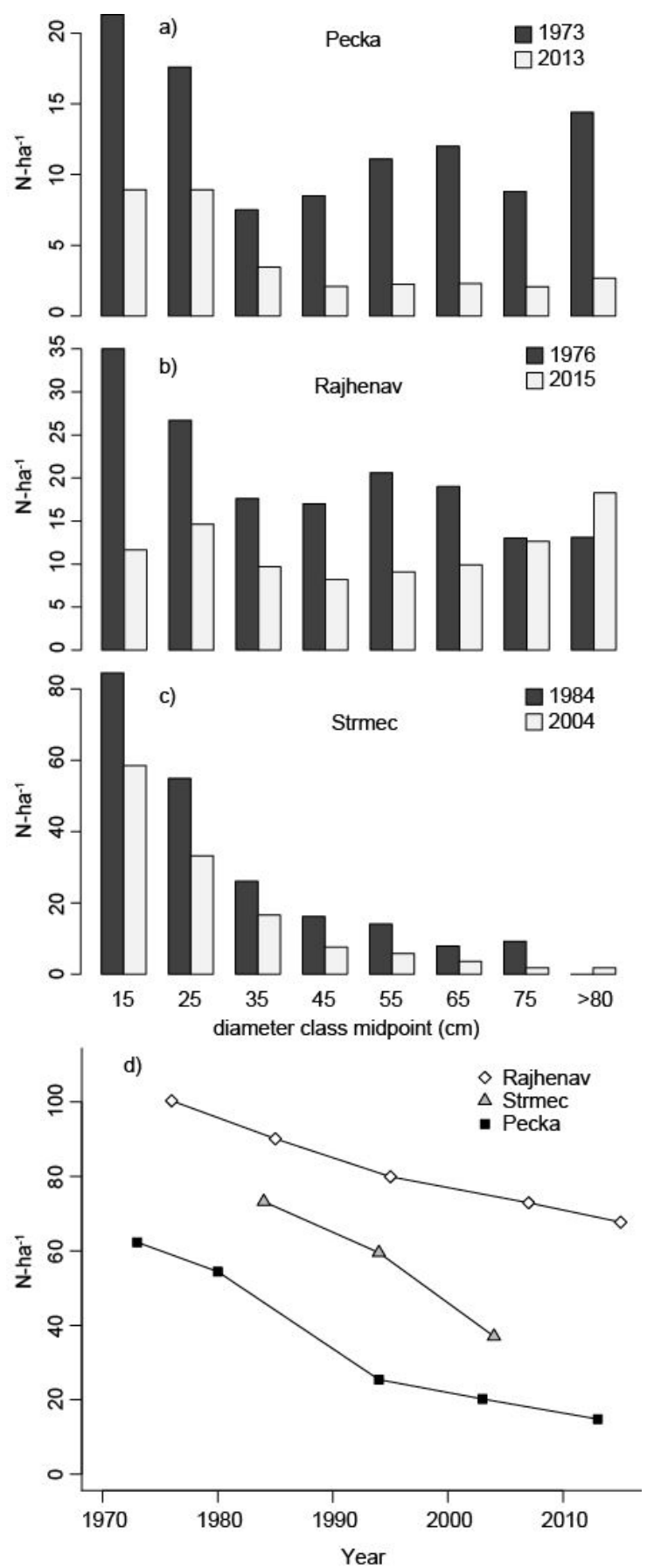

Figure 1. Decline of Abies alba across the three old-growth forest reserves during the past four decades. Diameter distributions (at $1.37 \mathrm{~m}$ ) in $10 \mathrm{~cm}$ size classes from available inventory years closest to the understory surveys in this study for the (a) Pecka, (b) Rajhenav, and (c) Strmec study sites, and (d) the density of canopy-sized $A$. alba trees $>30 \mathrm{~cm}$ in diameter for all available inventory years during the past four decades at the three sites. Data were extracted from complete inventories carried out approximately every decade, in which all live trees were tallied within $5 \mathrm{~cm}$ diameter classes in each reserve. 

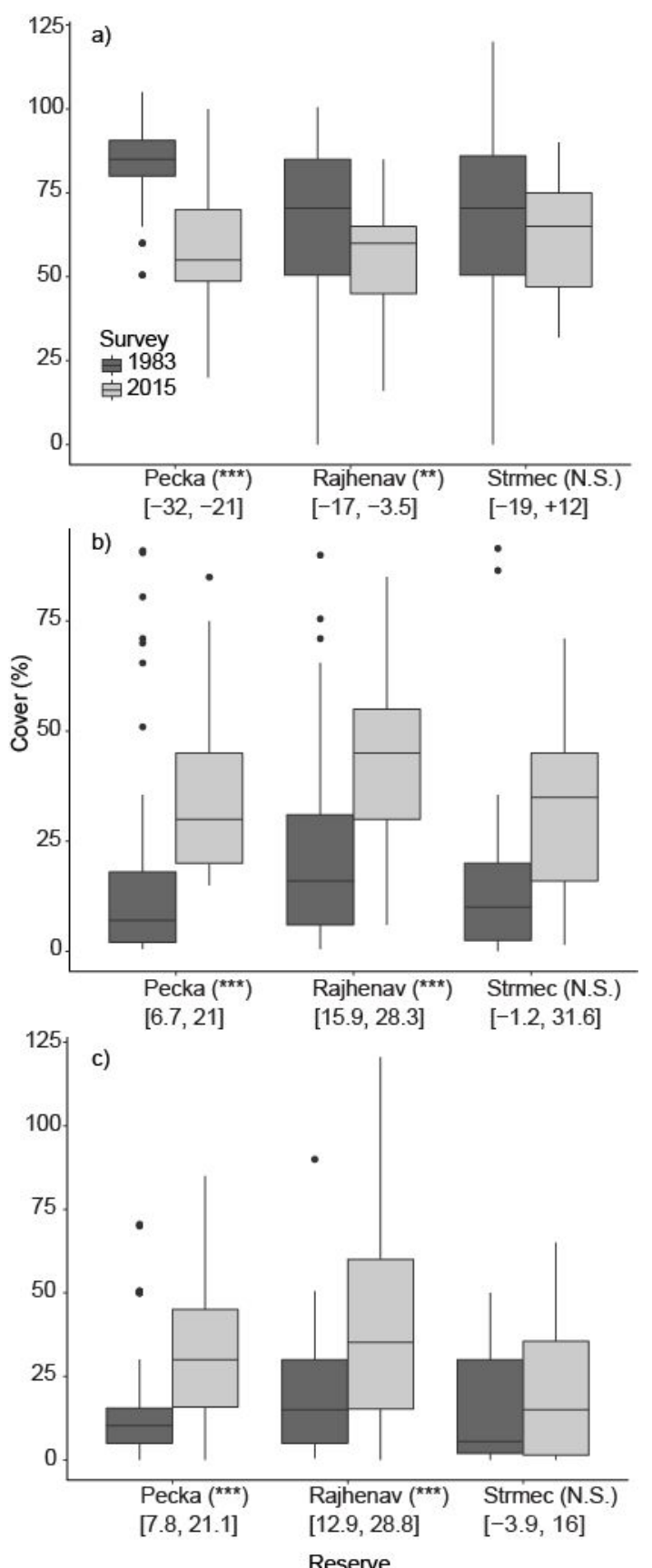
Reserve

742 Figure 2. Box plots showing plot-level changes in cover of a) canopy, b) subcanopy,

743 and c) regeneration layers between 1983 and 2015 across the three old-growth forest

744 reserves. Statistical differences in cover between the two survey years and $95 \%$

745 confidence intervals of the difference are indicated on the $\mathrm{x}$-axis (paired t-tests, $* * P<$

$7460.01 ; * * * P<0.001)$. 


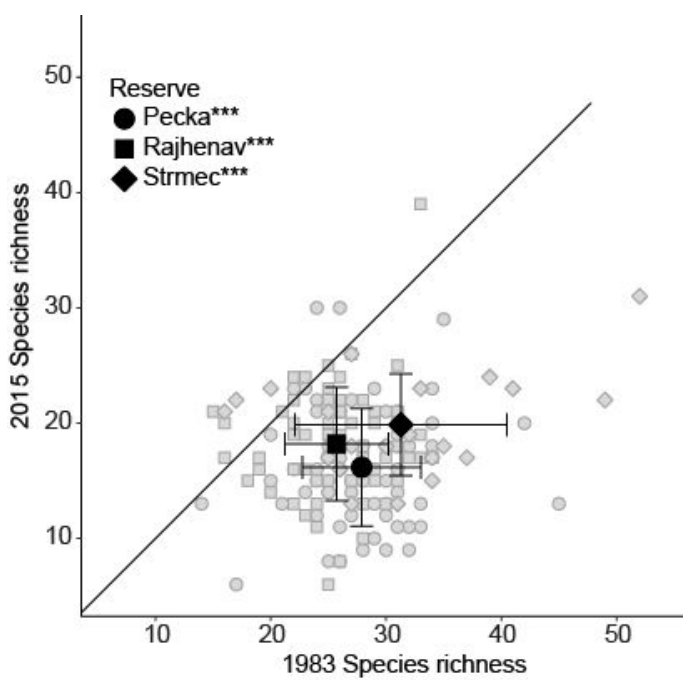

752 Figure 3. Plot-level changes in species richness between 1983 and 2015 across the three old-growth forest reserves. The line indicates a 1:1 relationship of no change. The grey symbols denote individual plots, while the black symbols show the mean change for each reserve. Statistical differences between the survey years are indicated in the legend (Wilcoxon signed rank tests, $* * * P<0.001$ ). The decline in species richness was also significant $(P<0.001)$ for the pooled dataset based on a linear mixed effects analysis $(P$ $<0.001$ ) (Appendix S6).

759

760

761

762

763

764

765

766

767

768

769

770

771

772

773

774 


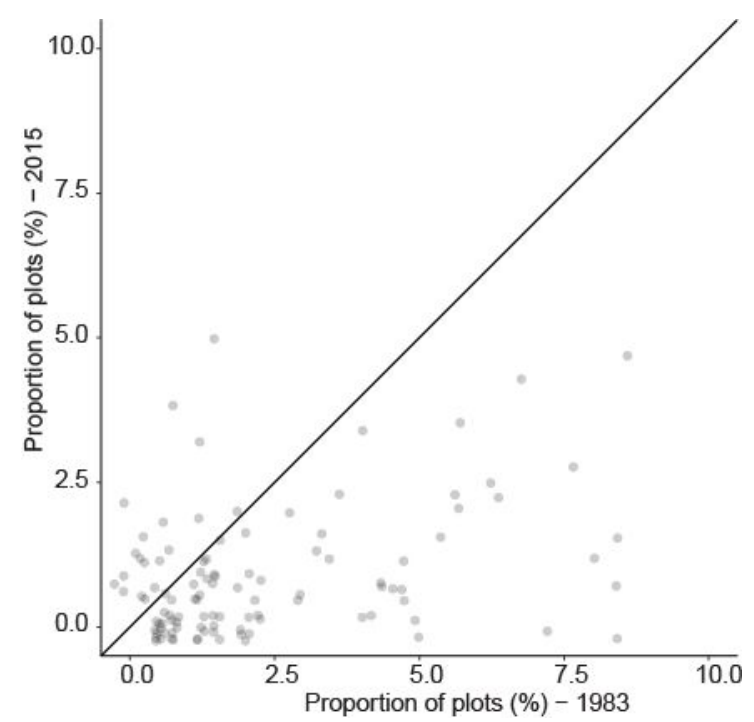

776

Figure 4. Changes in the frequency of rare species between 1983 and 2015 across the pooled dataset from the three old-growth forest reserves. Rare species were defined by those present in $<10 \%$ of plots in 1983 inventories. The line indicates a 1:1 relationship of no change. Note that a dispersion function was used to better illustrate those species that were no longer present in 2015.

782

783

784

785

786

787

788

789

790

791

792

793

794

795

796

797

798 

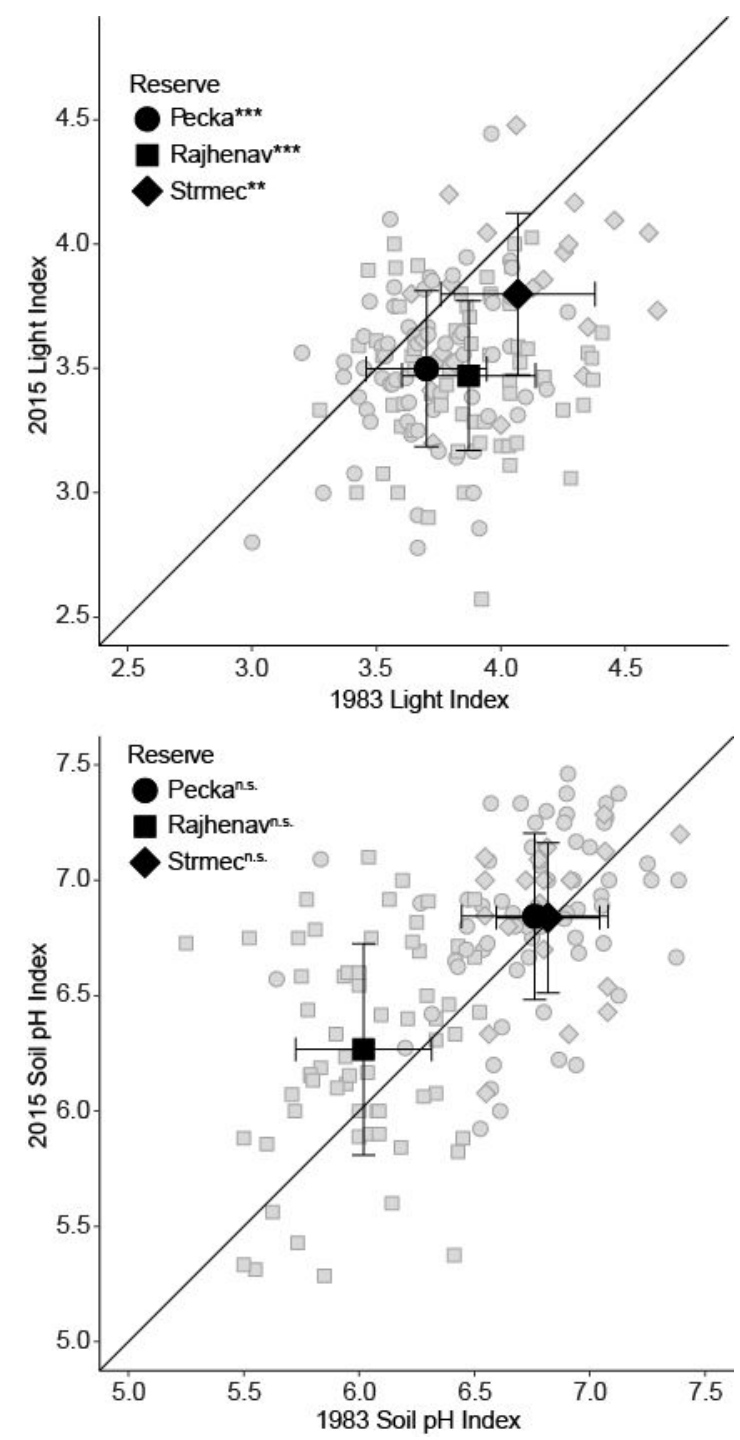

800 Figure 5. Plot-level changes in Ellenberg indicator values for light and soil reaction/pH

801 between 1983 and 2015 across the three old-growth forest reserves. Note that lower

802 values of the light index indicate shade, while higher values correspond to increased

803 light. Lower values for the $\mathrm{pH}$ Index indicate more acidic conditions, while higher

804 values more alkaline. Lines indicate a 1:1 relationship of no change. The grey symbols

805 denote individual plots, while black symbols show the mean change for each reserve.

806 Statistical differences between the survey years are indicated in the legend (Wilcoxon

807 signed rank tests, n.s.: not significant; $* * P<0.01$; $\left.{ }^{* * *} P<0.001\right)$. Changes in both the

808 light and soil reaction/pH index were significant for the pooled dataset based on a linear

809 mixed effects analysis $(P<0.001)$ (Appendix S6). 

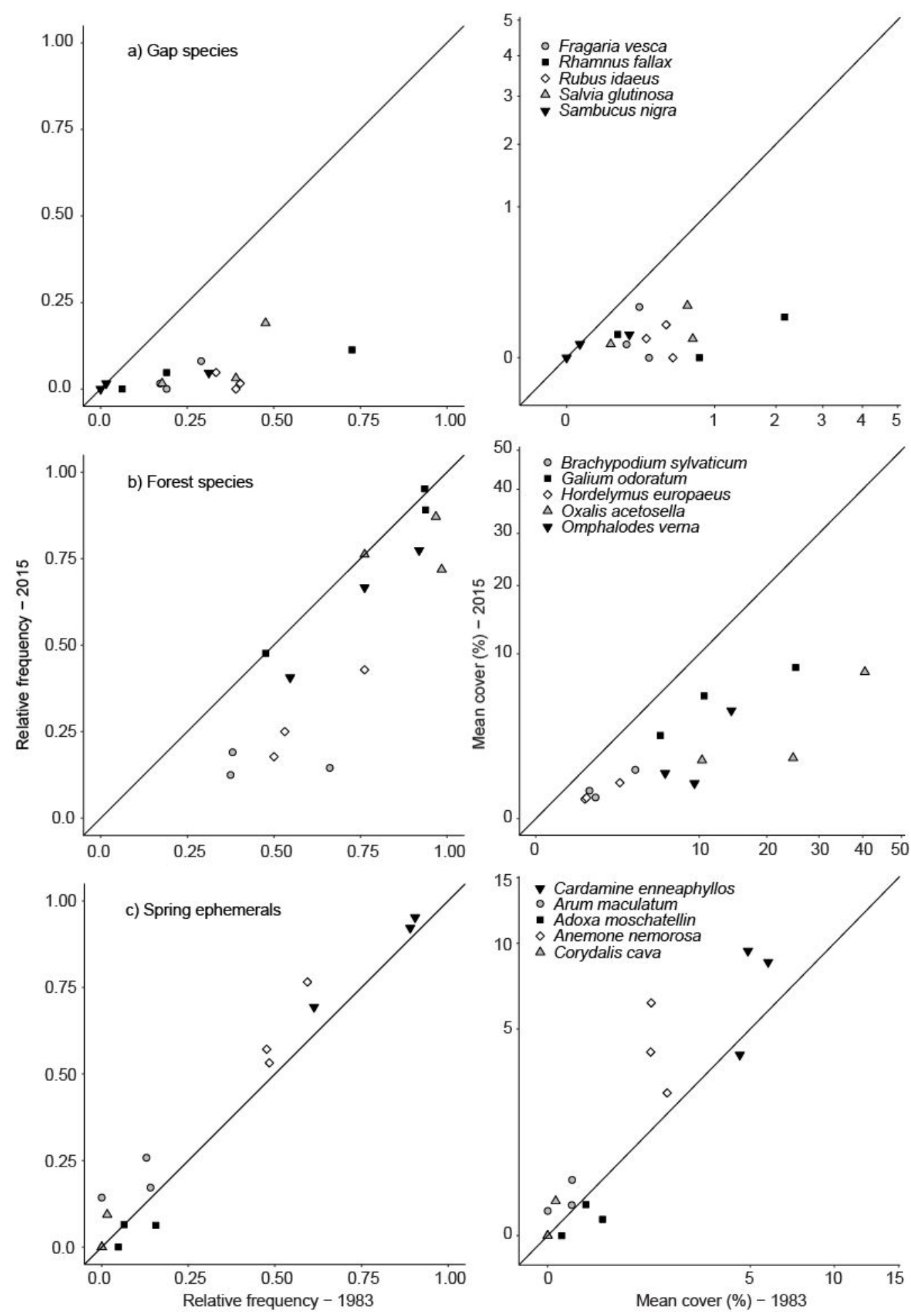

812 Figure 6. Changes in relative frequency and mean cover of selected species between

8131983 and 2015 across the three old-growth reserves. The species were selected to

814 illustrate different responses to the cascading effects of Abies alba decline based on

815 their contrasting life histories. They include (a) light demanding species that typically

816 occur in forest gaps, (b) common species typical of the forest understory with 
817 characteristics such as high shade tolerance or summer green foliage that were frequent

818 across the study sites, and (c) spring ephemerals. Frequency and cover values are shown

819 for each reserve. Lines indicate a 1:1 relationship of no change. Note the square root

820 transformation of the $\mathrm{x}$-axis for mean cover.

821

822

823 Supporting Information

824

825 Appendix S1: Vegetation cover and height classes

826

827 Appendix S2: Archival surveys of regeneration density

828

829 Appendix S3: Soil characteristics

830

831 Appendix S4: Beta diversity analysis

832

833 Appendix S5: Indicator species analysis

834

835 Appendix S6: Linear mixed effects analysis 

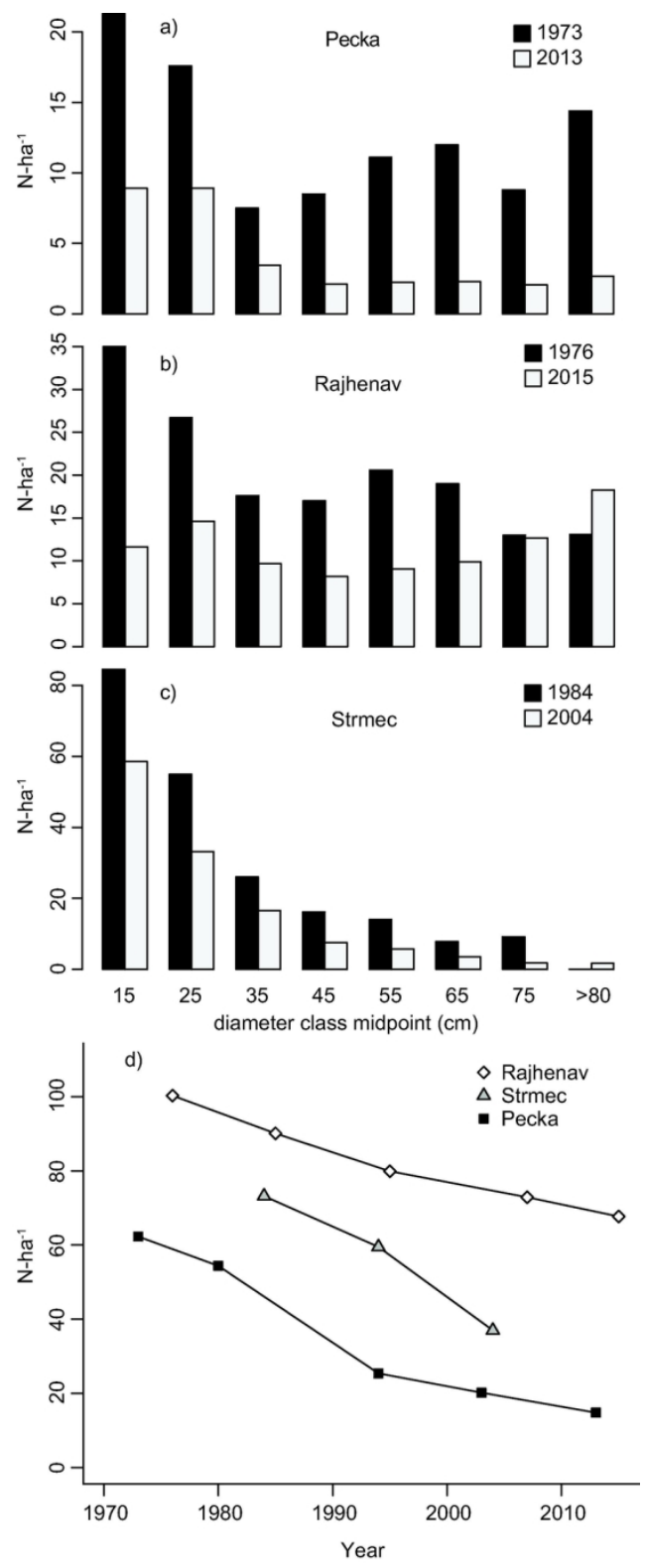

Figure 1

$75 \times 184 \mathrm{~mm}(300 \times 300 \mathrm{DPI})$ 

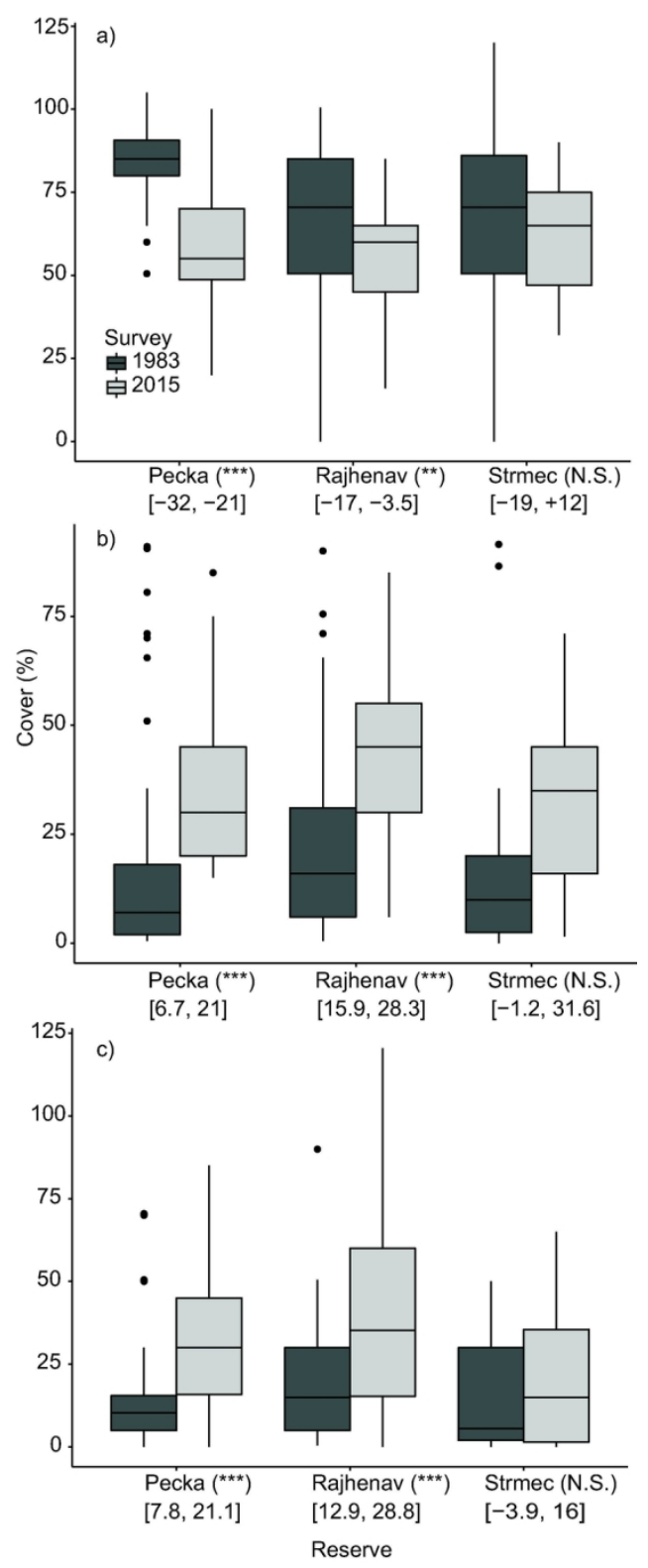

Figure 2

$70 \times 175 \mathrm{~mm}(300 \times 300 \mathrm{DPI})$ 


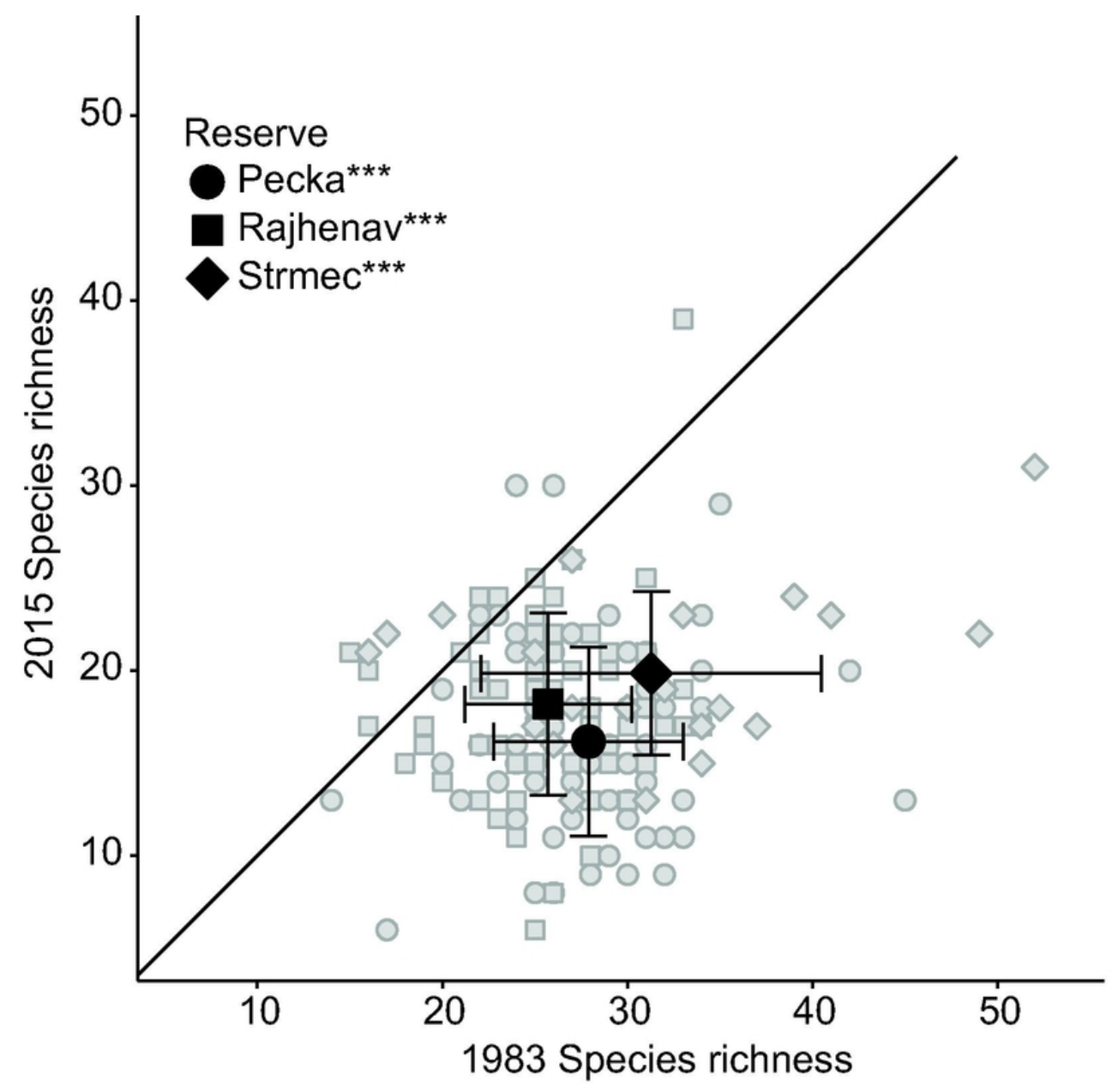

Figure 3

$70 \times 67 \mathrm{~mm}(300 \times 300 \mathrm{DPI})$ 


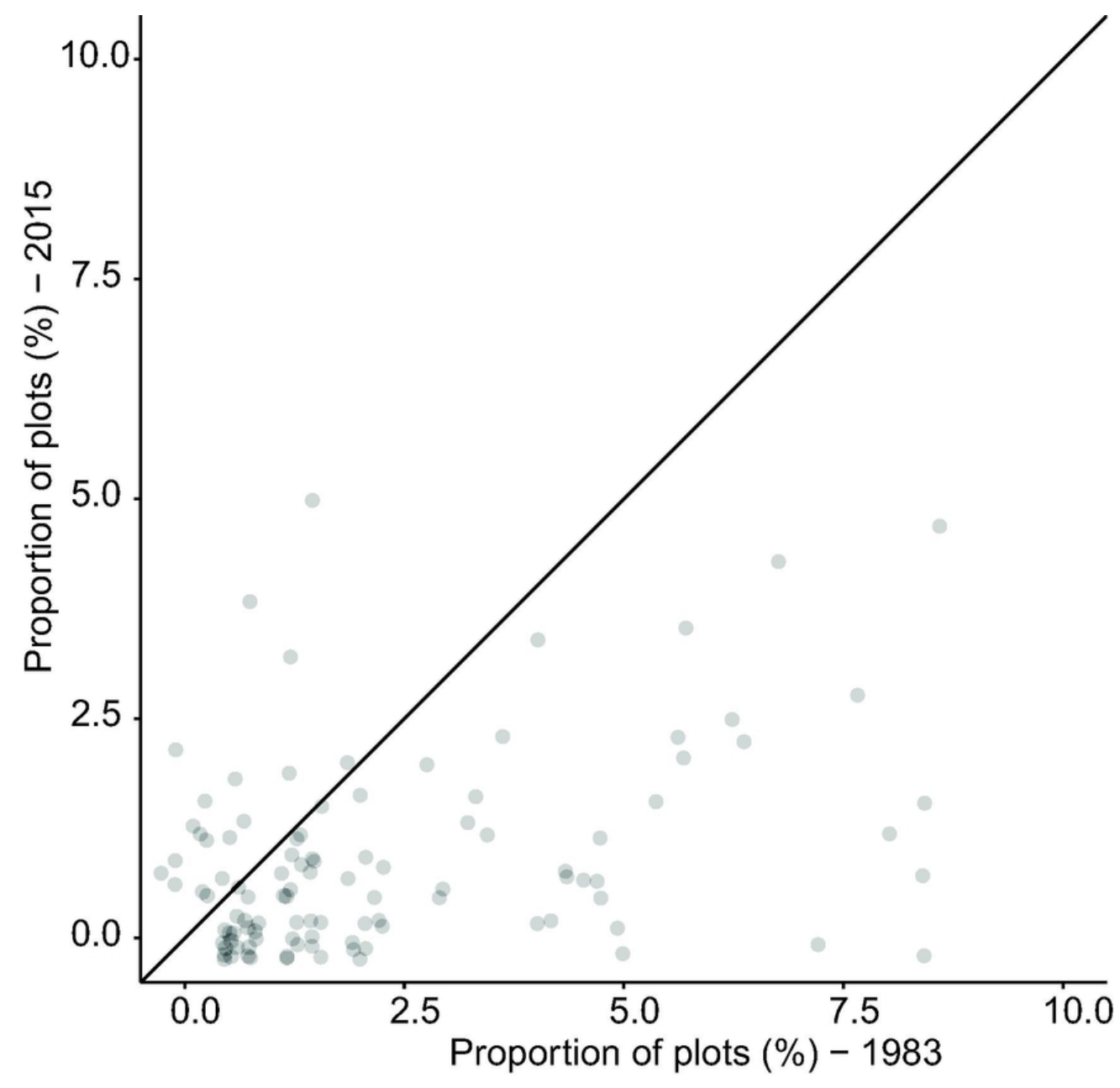

Figure 4

$73 \times 70 \mathrm{~mm}(300 \times 300$ DPI $)$ 

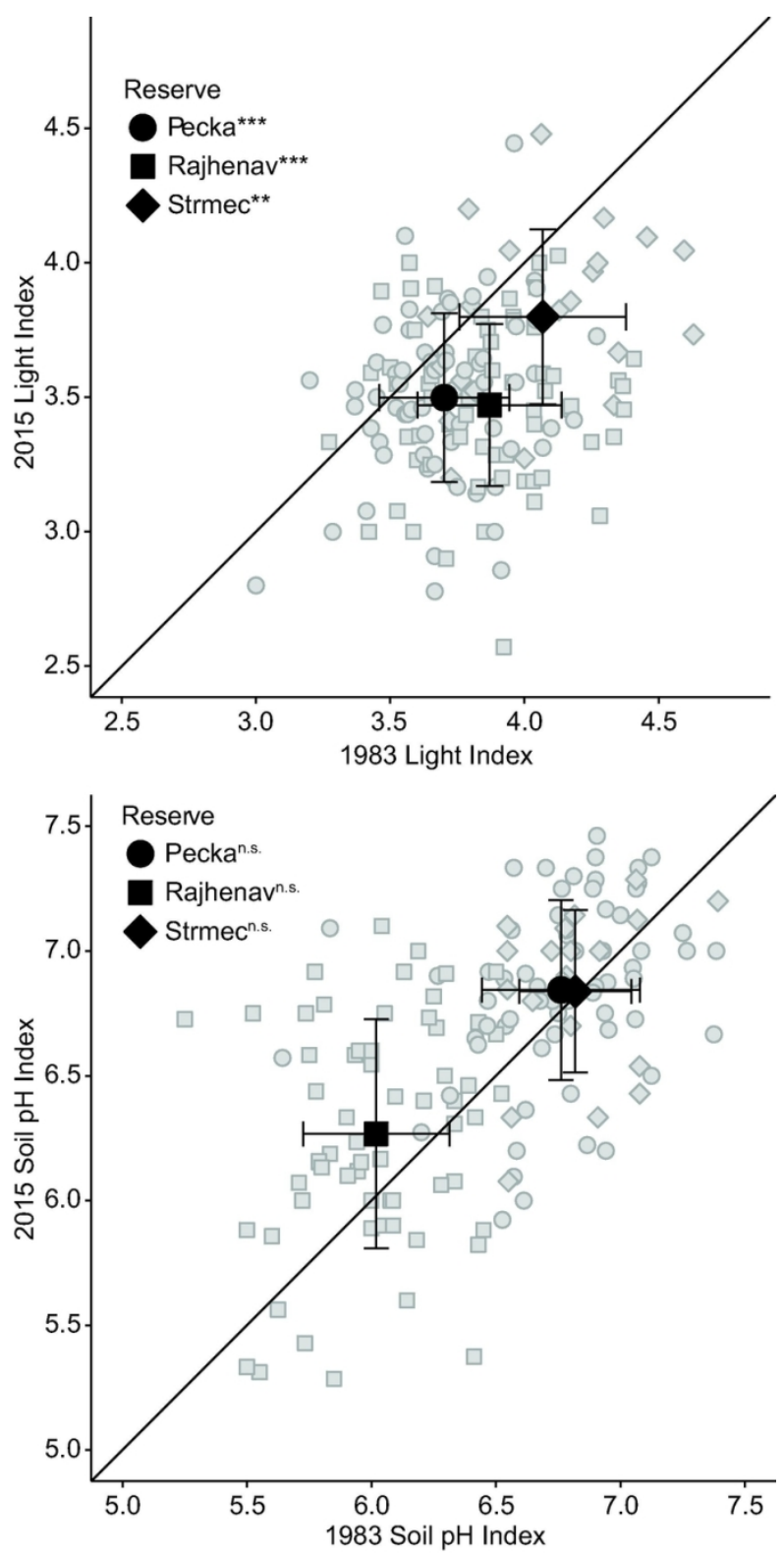

Figure 5

$71 \times 144 \mathrm{~mm}(300 \times 300 \mathrm{DPI})$ 

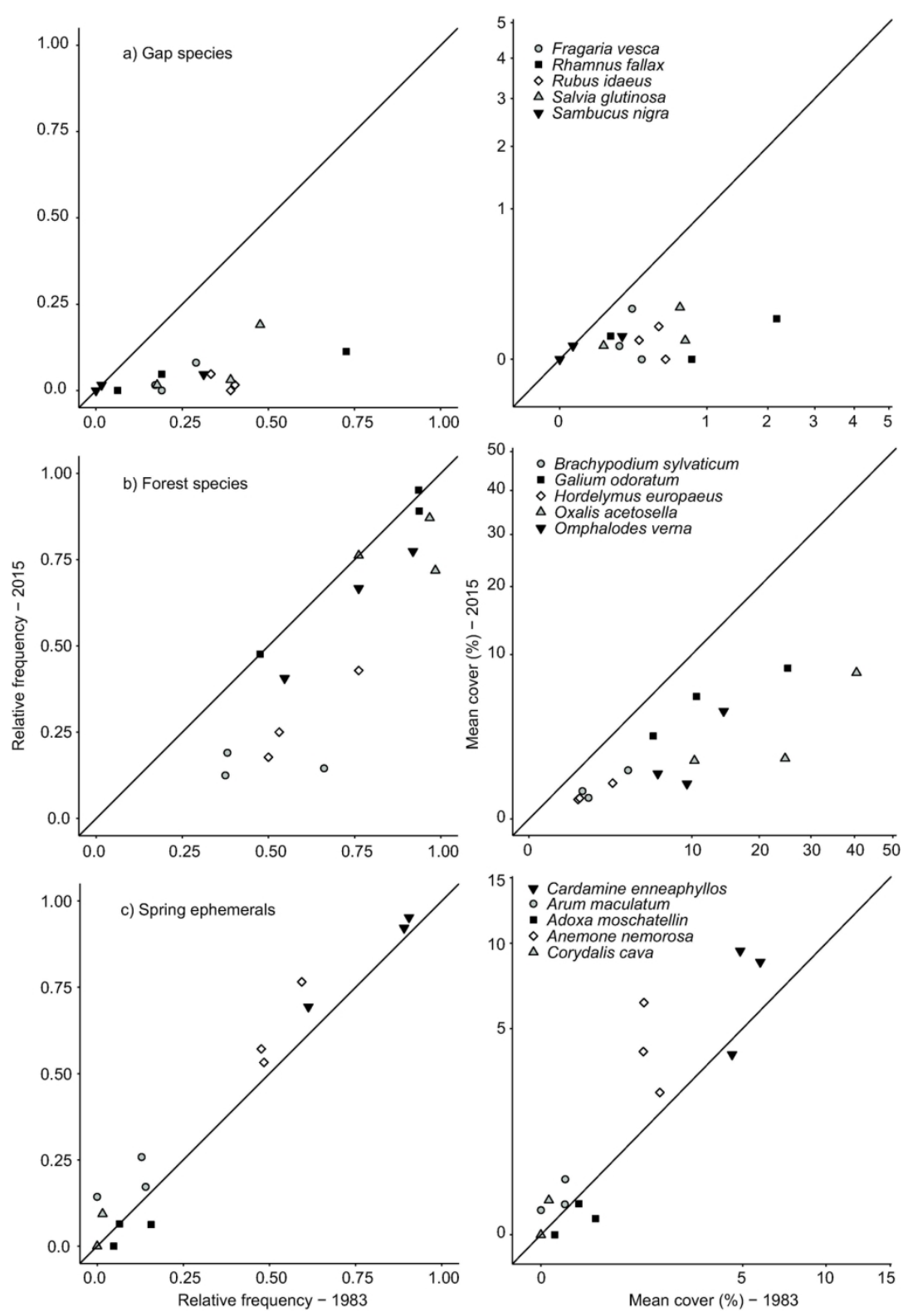

Figure 6

$134 \times 196 \mathrm{~mm}(300 \times 300$ DPI $)$ 


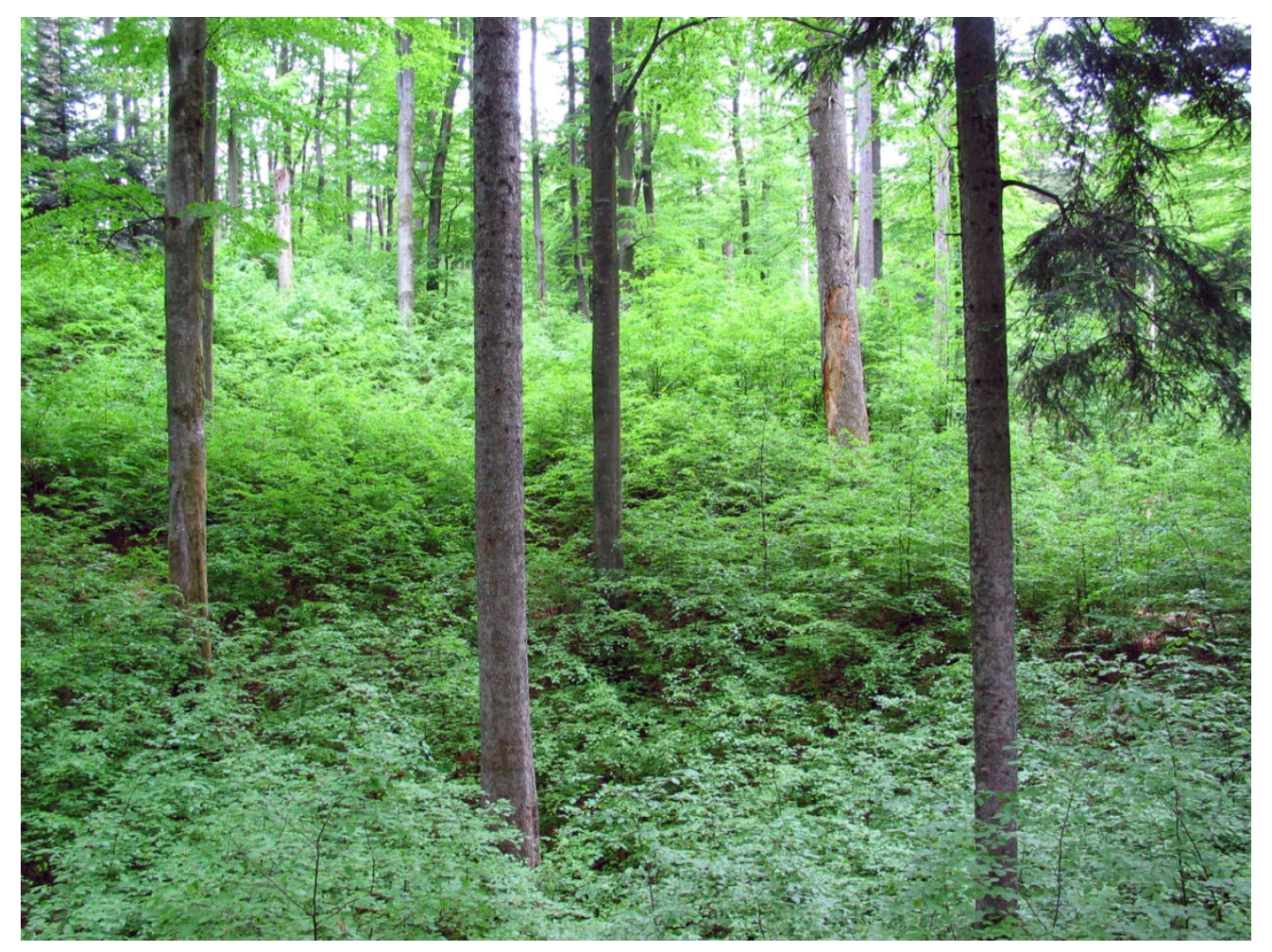

119x89mm (300 x 300 DPI) 
We examined how long-term mortality of a foundation conifer tree influenced understory vegetation dynamics. Canopy mortality caused a recruitment pulse of broad-leaf regeneration, which resulted in a significant loss of herb diversity and homogenization of the understory community. This study sheds light on the potential cascading consequences triggered by episodes of increased tree mortality resulting from global change type drivers. 